\title{
Social enterprise in a remote Indigenous community - Barunga Festival in Australia's Northern Territory
}

\author{
Prescott C. Ensign (it) \\ Lazaridis School of Business and Economics, Wilfrid Laurier University, 75 University Ave W, Waterloo, Ontario N2L \\ 3C5, Canada \\ Corresponding author. Prescott C. Ensign, E-mail: ensign@wlu.ca
}

(Received 12 September 2020; revised 9 December 2020; accepted 18 December 2020)

\begin{abstract}
In 2020, the Barunga Festival would have celebrated its 35th anniversary. In mid-June of 2021, as many as 4,000 individuals were expected to descend on an aboriginal community of 300 residents located $400 \mathrm{~km}$ south of Darwin. This case describes the challenge to the Festival's promoters as they seek to sustain peak socio-economic impact in their role as community development change agents in a diverse and dynamic environment. The reader is tasked with clarifying goals, deciding what is at stake, and setting a course of action to realize those objectives.
\end{abstract}

Key words: Community development; funding dynamics; social enterprise; sustainability

The Barunga Festival was built on the premise of reconnecting people from Indigenous communities across Australia's Northern Territory and promoting an honest, open, and authentic mingling of Indigenous and non-Indigenous people. The Festival had been predominantly apolitical but had the subtle goal of overcoming paternalistic attitudes of outsiders by welcoming them to a remote Indigenous community. Festival Director, Mark Grose recognized that the tyranny of distance had not passed. Few non-Indigenous Australians socialized with Indigenous Australians, creating significant barriers.

The Festival had been going strong for many years. A lot had changed, but much remained the same: content; venue; and, consistent delivery of a stellar experience. Problems had been consistent, too: attracting non-Indigenous festivalgoers and providing fresh talent to keep festivalgoers engaged. One of the Festival's strengths was the delivery of healthy lifestyle messages to the region's Indigenous population. How to keep that component relevant, and how to fund the cultural offerings were major issues. Looking to 2021 and beyond, there was recognition that things were not as precarious as years prior, ${ }^{1}$ but there was still much to be done. There was hope for both continuity and improvement. The Festival team reflected and asked the open-ended question: What must be done now and how shall we do it?

\footnotetext{
${ }^{1}$ In reference to the 2012 Barunga Festival, the Australian Broadcast Corporation's Radio Darwin stated 'The Barunga Festival came close to collapse this year... but was saved at the last minute with the help of Indigenous music company SkinnyFish. There have been nine festival coordinators in the past 10 years, and that takes its toll.' 


\section{Changing festival leadership}

The Jawoyn Association Aboriginal Corporation (JAAC) assumed oversight of the Barunga Festival in 2008. JAAC sought preservation of traditional and current Indigenous culture. JAAC's agenda focused on sustainable improvements in economic, social, and education indicators including comprehensive human services, cultural and land management programs, and enterprise development with a vision for economic independence. Australia's top 500 Indigenous corporations generated a combined income of nearly $\$ 2$ billion and employed over 11,000 . Over $\$ 900$ million went to such corporations in the Northern Territory. ${ }^{2}$

Six weeks before the 2012 Festival was to open, JAAC called in Mark Grose and Skinnyfish Music to rescue the Festival. This decision was the culmination of the preceding 10 chaotic years. Skinnyfish Music was based in Darwin, Australia. Darwin with a population of nearly 150,000 was the capital of the Northern Territory which had a population of just under 250,000. Darwin was located 4,000 km north of Sydney on Australia's northern coast and just across the sea from Indonesia. Skinnyfish Music was a music label founded in 1999 by Mark Grose and Michael Hohnen to:

maximize the positive impact that music can have on people's lives while providing a window to the richness of indigenous Australian culture... work in partnership with artists and their communities to produce music by, about and for them, and take their music to the wider world.

Grose and Hohnen - through Skinnyfish Music - recorded and promoted the work of Indigenous musicians. Their goal was to empower Indigenous Australians to pursue their own creative and economic activity.

Skinnyfish is committed to building long term relationships with musicians, their families and communities; and connecting with Australian and international artists, private organisations, government departments, and other associations that have significant influence on indigenous communities. ${ }^{3}$

After completion of the 2012 Festival, Grose and Skinnyfish Music were given the responsibility to manage the Festival for the next 5 years. It was hoped that their reputation among Indigenous communities would contribute to greater engagement and success for future Festivals. Grose was committed to returning the Barunga Festival to its high-profile status. ${ }^{4} \mathrm{He}$ believed that 'Music [was] a really powerful model' and '[could] be used as an agent for positive change.' He indicated 'Skinnyfish was in for the long run.' Grose and Skinnyfish Music had plans to invest more time and resources in community festivals:

Community festivals are such an important part of community life and positive outcomes for Indigenous people. Musicians and artists in general aren't utilised well enough by government departments and all those agencies that want to carry messages into remote communities. You take a band into a remote area and the entire community stops and listens. ${ }^{5}$

Reaching a wider community in 2017, TEABBA (Top End Aboriginal Bush Broadcasting Association) had come onsite with a truck loaded with equipment and streamed Festival events

\footnotetext{
${ }^{2}$ Office of the Registrar of Indigenous Corporations.

${ }^{3}$ https://www.skinnyfishmusic.com.au/about.

${ }^{4}$ The political apex was in 1988, when Australian Prime Minister Bob Hawke was presented with The Barunga Statement, paintings and text written on bark with Indigenous demands. Over the years, headlining acts have included Peter Garrett (frontman for the band Midnight Oil, environmentalist, and politician), Gurrumul, Missy Higgins, and Courtney Barnett.

${ }^{5}$ Australian Broadcast Corporation Radio Darwin (2012) Gurrumul tipped to perform at revitalized Barunga Festival (28 November) (http://www.abc.net.au/local/stories/2012/11/28/3642960.htm).
} 
live and were committed to return in 2018. The 2018 and 2019 iterations of the Barunga Festival received critical acclaim, but the team now, including Festival Coordinator Brad Firebrace, had to decide what further success would look like or entail.

\section{Public relations/marketing strategy/funding dynamics}

Early in 2013, Barunga, the Festival, and the region underwent a period of negative media attention. JAAC was accused of internal strife, improper use of funds, and ousting of officers. By July 29, the Registrar of Indigenous Corporations determined that no criminal or civil action would be taken in relation to the complaints. News coverage of such magnitude had a negative impact on Festival operations. But despite setbacks, the Festival was headed in a positive direction. The Baraga Aboriginal Corporation from the Barunga Community was registered in January of 2014 for the purposes of advancing culture and advancing social or public welfare. ${ }^{6}$

The post-2013 Festival media coverage was favorable, touting it as 'revived' and 'reinvigorated'; Grose and the team were credited with keeping alive the traditions of a people who were coming to terms with tourism. As Grose told the press,

If this turned into a festival where everything was geared to please whitefellas, the Aboriginal people would just walk away. Barunga is about black and white saying 'let's get together, have fun, watch some footy, buy some art.' Whitefellas come to experience community life and for us it's about saying 'We're not going to change that to suit you."

\section{As Kris Keogh of the Northern Territory News stated,}

The generosity and willingness of Indigenous people to share their culture made the whole event a truly amazing experience. Seeing those thousands of Indigenous and non-Indigenous people camping out, sharing and celebrating being together made me so hopeful for the future of the Territory.

Funding had been a mix of grants, sponsorships, booth rentals, and attendee event tickets. But roadblocks were always there. Just days before the 2015 Barunga Festival, news was released that funding had been 'smashed.' A funding application under the Indigenous Advancement Strategy was turned down. Despite setbacks, Grose had not been deterred. Now, a handful of years later the situation was still similar - always precarious. Sponsorship of the Festival was offered in tiers of: $\$ 2,500, \$ 5,000, \$ 10,000$, and $\$ 20,000$. The Northern Territory Major Events Company delivered an Event Funding Program on behalf of the Northern Territory Government, but there was always much groundwork to be done and phone calls to make.

\section{Core festival agenda: change, but no change}

Coming together and sharing experiences was at the center of Peter Miller's desire when he founded the event. According to Miller, the festival was about 'Getting people here to share their ideas about their life in the past, their life today, and perhaps their adventurous ideas for the future development of this country.' According to the Australian Broadcasting Corporation, 'The example of the Barunga Festival is clear: music can be a key to reconciliation. May big things continue to grow from this little festival. ${ }^{8}$

\footnotetext{
${ }^{6}$ Australian Charities and Not-for-profits Commission (https://www.acnc.gov.au/charity/8f6elf535dcee145891a09f198873153).

${ }^{7}$ The Guardian (2013) How Australia's Barunga Festival keeps alive the Aboriginal spirit (21 June) (https://www.theguardian. com/travel/2013/jun/21/australia-aboriginal-barunga-festival-northern-territory).

${ }^{8}$ ABC News (2015) Paul Kelly, Gurrumul \& Peter Garrett eclipsed at outback festival (12 June) (https://www.abc.net.au/doublej/music-reads/features/paul-kelly-gurrumul-38-peter-garrett-eclipsed-at-outback-festiva/10271506).
} 
Exhibit 1: Barunga Festival - the essentials

Barunga is a dry community, and the Festival is a strictly drug- and alcohol-free event. Please note there will be police checks on the road to Barunga and your car may be searched.

Self-sufficient camping is the only option at Barunga. All campsites are unpowered and generators are not permitted. Campfires are permitted, but you must bring your own firewood.

There are no shower facilities, but there is a refreshing (croc-free) creek by the APRA Acoustic Tent.

Barunga Festival has a healthy food policy. A variety of food options are available at reasonable prices throughout the Festival in Heritage Park. The Outback (general) Store in Barunga is incredibly well stocked and surprisingly affordable. Support the community by buying locally if you can!

Source: https://www.barungafestival.com.au/essential-info.

Presenting a program for Indigenous people remained a core mandate. Traditional and modern Aboriginal life was showcased. More than 20 Indigenous communities from across the Northern Territory descended on Barunga to compete in sports such as Aussie rules, basketball, softball, spear throwing (at an effigy of a kangaroo $50 \mathrm{~m}$ away), and fire lighting. Visitors to the 3-day Festival held on the Queen's Birthday weekend ${ }^{9}$ were invited to camp in the community, be part of dancing ceremonies, share traditional bush tucker, make their own didgeridoo, weave a basket, cheer on modern and traditional athletic competitions, and enjoy plenty of great traditional and modern music from the region and beyond.

Grose told reporters, 'Previous coordinators tried to make this something more sophisticated than it should be, but the community gets lost in that. All of the activities here are things remote communities love. ${ }^{10}$ The Festival had been more than a stage for local, regional, rising Indigenous musicians. It provided an outlet for Indigenous community building and development. For example, the Northern Territory Stolen Generations Aboriginal Corporation sought to reconnect separated families over the Festival weekend. ${ }^{11}$ Other organizations took the opportunity to 'communicate healthy lifestyle messages in an open, celebratory setting.' This included the Department of Health (raise awareness of alcohol and drug abuse), Jobfind, a mobile dialysis bus, and Family Violence Legal Service.

Positive things continued to be added to the Festival agenda that highlighted the Indigenous people of the Top End. For example, walking tours by the Jawoyn Junior Rangers were a hit; local youth guided outsiders through the community and out into the savannah for an all senses foray into an unfamiliar and seemingly inhospitable land.

\section{Reflecting on the past: looking to the future}

Mark Grose had held the reins of the Barunga Festival for a handful of years and had hoped that new people would lead to new ideas. With his contract up, he and his team reflected on the past and looked to the future. Skinnyfish Music continued to play a role of support. Grose's role was really that of a social entrepreneur juggling an array of constituents. The business model was a mix of social value creation and revenue seeking. The trade-offs were complex, between keeping the community focus and achieving financial viability. Funding, competition with other festivals - Indigenous or otherwise, and public support were continuing issues. With a variety of stakeholders and trade-offs, the Festival had benefited markedly from his leadership and direction.

In pitching the Festival to the media, Mark Grose stated,

The event is stronger than ever and attracts Indigenous clans from across the Northern Territory and beyond where they can meet, compete, discuss and celebrate their links and

\footnotetext{
${ }^{9}$ The holiday was the second Monday in June.

${ }^{10}$ The Guardian (2013).

${ }^{11}$ Stolen generations refers to the removal of Aboriginal children from their parents.
} 
Table 1. Barunga Festival attendance and ticket pricing

\begin{tabular}{|c|c|c|}
\hline & Attendance & Admission \\
\hline & $\begin{array}{l}\text { Peaked in the } 1990 \text { s reaching } 6,000 \\
\text { waning prior to } 2012\end{array}$ & \\
\hline 2013 & $\begin{array}{l}4,000 \text { ( } 70 \% \text { Indigenous, } 30 \% \\
\text { non-Indigenous) }\end{array}$ & $\$ 30 /$ adult, $\$ 10 /$ child, under 12 free camping no charge \\
\hline 2014 & 3,000 & $\$ 35 /$ adult, $\$ 10 /$ child, under 12 free camping no charge \\
\hline 2015 & 3,750 & $\$ 40 /$ adult, $\$ 10 /$ child, under 12 free camping no charge \\
\hline 2016 & 4,000 & $\$ 50 /$ adult, $\$ 15$ ages $12-17, \$ 5$ ages $2-11$ \\
\hline 2017 & $3,500+$ & $\$ 50 /$ adult, $\$ 15$ ages $12-17, \$ 5$ ages $2-11$ \\
\hline 2018 & 4,000 & $\$ 50 /$ adult, $\$ 15$ ages $12-17, \$ 5$ ages $2-11$ \\
\hline 2019 & $3,000+$ & $\$ 55 /$ adult, $\$ 15$ ages $12-17, \$ 5$ ages $2-11$ \\
\hline 2020 & Canceled due to COVID-19 & $\$ 59 /$ adult, $\$ 22$ ages $12-17, \$ 7$ ages $5-11$ \\
\hline 2021 & & $\$ 59 /$ adult, $\$ 22$ ages $12-17, \$ 7$ ages $5-11$ \\
\hline
\end{tabular}

diversity. It's also a place for non-Indigenous people to come and get a taste of the real Australia with their families. ${ }^{12}$

The focus on showcasing the region and supporting remote Indigenous communities had been maintained. Sponsors had been sought to aid in promoting the positive aspects of community life. Visitors continued to be given an opportunity to engage with a remote Indigenous community (see Table 1). But as Grose indicated,

It's about local community people doing their thing and saying to the rest of the world, 'come and join us, come and be part of what we're doing and sit with us and talk to us as friends, not as some political or cultural exchange.' If no whitefellas came to Barunga Festival, it would still happen. ${ }^{13}$

Sports had been a lynchpin of the Festival and the music was a huge draw.

Participation in sport in remote communities is an important aspect of everyday life. Where job opportunities are limited in the bush, the opportunity to be involved in a positive organised activity is an important means by which individuals can contribute to their community's wellbeing and identity.

The football program brings together teams from the region and gives young players an opportunity to shine in front of a large audience. Basketball is keenly contested with teams from as far as the East Kimberly and Central Australia. Softball is an all-time favourite sport at Barunga and is a truly family affair with mothers, daughters and grandmothers all playing on the same team. ${ }^{14}$

\footnotetext{
${ }^{12}$ Sounds of $\mathrm{Oz}$ - Australian music news and reviews (2015) (http://www.soundsofoz.com/2015/05/06/paul-kelly-gurrumul-and-more-to-play-30th-barunga-festival/).

${ }^{13}$ Traveller.com.au entry by Andrew Bain (2015) (https://www.traveller.com.au/barunga-festival-30th-anniversary-northern-territory-bare-feet-stamping-in-australias-top-end-1mm6v8).

${ }^{14} 2014$ Barunga Festival Program (http://ropergulf.nt.gov.au/wp-content/uploads/2014/03/Barunga14_progWEBspreads. pdf), see also the list of event sponsors.
} 
As part of its marketing and funding strategy going forward, the Festival called for support of its efforts. For example, the following 'Expression of Interest' was presented.

With its long history and proud tradition of celebrating life and attracting people from far and wide, Barunga Festival offers a unique and valuable opportunity for small businesses to showcase and sell their products, for stalls to provide nutritious food to the audience and for both non-government and government service providers and community groups to engage their clients. The Barunga Festival Organising Committee invites groups and organisations to apply to have a food stall, commercial stall or an information booth at the 2018 Barunga Festival. A crowd of over 4,000 people is expected. ${ }^{15}$

2018 marked an all indigenous line-up of entertainment. Brad Firebrace told the press he was thrilled, sharing 'We haven't got a headline act because we don't think the festival needs that. People come to the Barunga Festival to experience it as a whole. ${ }^{, 16}$ The March/April 2019 issue of the magazine Australian Geographic featured the Barunga Festival and titled the article 'Listen Learn Live.'

The 2019 Barunga Festival organizers hoped to do as well as previous iterations but had fewer attendees $(3,000+)$. Although Skinnyfish Music remained a sponsor for 2019, Brad Firebrace was now the Festival Coordinator and Coco Eke was now Partnerships Manager. She had been Sponsorship and Marketing Coordinator - a capacity she had worked in under Mark Grose's tutelage. Previously tasked with the Culture Program, Firebrace too overlapped with Mark Grose. In addition to Skinnyfish Music's continued involvement, NT Major Events Company had joined in the effort. NT Major Events Company and Skinnyfish Music were prominently featured on social media during the Barunga Festival 2020 road tour.

In reviewing the past, the Barunga Festival was a national icon - yet there were competitors.

Garma Festival of Traditional Cultures was a celebration of the Yolngu culture in Arnhem land held in August. It touted itself as Australia's Indigenous equivalent to the World Economic Forum held annually in Davos, Switzerland. Ticket pricing was $\$ 1,500$ for a child or student, $\$ 2,500$ for an adult, and $\$ 4,000$ for a corporate ticket sold in groups of 10 . This pricing was an all-inclusive package (transport to/from airport, meals, and lodging for 4 days). The 2020 Festival went on hiatus during the COVID-19 pandemic.

The Laura Aboriginal Dance Festival was a biennial event held in Cape York in July. The last one was held in 2017 and though the next one would have occurred in 2019, it was scheduled for 2020 to coincide with the 250th anniversary celebration of James Cook's landing. The Festival website noted 'The festival has been coordinated by several different organisations over the years and in 2020... Returning to its rightful Traditional Owners, Ang-Gnarra Aboriginal Corporation will conduct and manage the festival. ${ }^{17}$ The Festival was canceled for 2020 due to the corona virus epidemic and rescheduled with a plea that 'our current government grant providers, sponsors and supporters stay the journey as we prepare for July 2021.'

The Cairns Indigenous Arts Fair was a 3-day event held annually in July and had a vision to support the careers of Queensland Indigenous artists 'by providing a platform for exposure and income generation.' The focus was on offering an 'ethical market place, attracting national and international collectors and curators, commissioning new work and providing pathways for emerging visual and performance artists. ${ }^{18}$ Evolve or abort were the choices for the 2020 Cairns Indigenous Arts Fair. To comply with social distancing, the Fair migrated online with virtual

\footnotetext{
${ }^{15}$ https://www.barungafestival.com.au/become-a-stallholder.

${ }^{16}$ Northern Territory News (2018) Barunga community ready to celebrate (6 June) (https://www.ntnews.com.au/entertain ment/barunga-community-ready-to-celebrate/news-story/bf9335399ff199d9af85f2cf50d1d92f).

${ }^{17}$ Ang-Gnarra Aboriginal Corporation - Laura Dance Festival (https://www.anggnarra.org.au/our-country/laura-dancefestival).

${ }^{18}$ Cairns Indigenous Art Fair (https://ciaf.com.au/about-cairns-indigenous-art-fair-0).
} 
exhibits and live streamed events. Artists continued to display their creations and continued to sell them. Event organizers stated they would keep the digital platform even when the physical fair returned. ${ }^{19}$

Parrtjima - a Festival in light ran after being rescheduled to September of 2020 and would return to April in 2021. Held in Alice Springs, it claimed to be 'the only authentic Aboriginal festival of its kind, showcasing the oldest continuous culture on earth through the newest technology.' It was a free event and 'celebrated the ways in which artists evolve and experiment.' The Festival's news releases boasted bringing $\$ 1.8$ million to the Alice Springs economy and attendance of over 25,000 in 2019, a quarter more visitors than in 2018.

Other festivals included Yabun and Spirit held in the urban locales of Sydney (January) and Adelaide (November) respectively. The Yabun Festival was held on Australia day and was touted as the largest single-day gathering and recognition of Aboriginal and Torres Straits Islander cultures in Australia with crowds of around 35,000 people. The Spirit Festival had evolved over the years and presently pitched itself as 'South Australia's premier Aboriginal and Torres Strait Islander arts and cultural festival,' showcasing art, music, dance, theatre, workshops, and more.

It was a bit disheartening that Australia Tourism did not list the Barunga Festival as one of ' 5 of Australia's most amazing Aboriginal festivals.' A fairly exhaustive list of 'Australia's best Indigenous festivals' however did include it. ${ }^{20}$ The 2020 Barunga Festival was initially postponed to September, but soon after that announcement the plug was pulled:

It is with great sadness that we inform you that Barunga Festival 2020 has now been cancelled. After consultation with the Barunga Committee, we feel it is in the best interest of the Barunga Community that it not go ahead this year. We look forward to bringing you a bigger \& better festival in $2021 .^{21}$

The Darwin Festival, however, went ahead as scheduled in August 2020 whereas the 3-day Wide Open Space festival an hour east of Alice Springs scheduled for May was canceled over health considerations.

It was decided to take 'Barunga on the road' and in September, Barunga Festival's Facebook page announced: 'We are hitting the road and going to visit different communities... posting updates along the way as we drive across 10,000 k's of the NT. Look out for the posts and if we end up in your community come and say hello.'

The Barunga Festival was a leader and had been a source of inspiration and renewal for so many. Now, the Festival's leadership considered how they could continue to cherish the past while working toward a bright future. Commitment and planning were required to achieve sustainability. What were the next steps to propel the Barunga Festival into success for this year and beyond? What needed to be done to ensure the Barunga Festival's financial stability and see it grow? $^{22}$

Acknowledgement. Funding for this research was provided by the Social Sciences and Humanities Research Council of Canada. Many people across turtle island helped to push me and this manuscript forward - Mahalo!

\footnotetext{
${ }^{19}$ Sharni Kim (2020) Cairns Indigenous Art Fair migrates online for 2020 and says virtual galleries here to stay. $A B C$ Far North (14 August) (https://www.abc.net.au/news/2020-08-15/cairns-indigenous-art-fair-migrates-online-due-to-coronavirus/ 12559690).

${ }^{20}$ Australian Traveller (2020) Australia's best Indigenous festivals (15 October) (https://www.australiantraveller.com/australia/ australias-best-indigenous-festivals/).

${ }^{21}$ https://m.facebook.com/barungafestival/.

${ }^{22}$ For those instructors using or considering using this case please contact ensign@wlu.ca for support materials.
} 